UDK 638.162+582.998.2]:537.31:662.613.11

\title{
CHARACTERIZATION OF SERBIAN SUNFLOWER HONEYS BY THEIR PHYSICOCHEMICAL CHARACTERISTICS
}

\author{
Milica M. Živkov Baloš, Sandra M. Jakšić, Nenad S. Popov*, Vladimir A. Polaček \\ Scientific Veterinary Institute "Novi Sad”, 21000 Novi Sad, Rumenački put 20, Serbia
}

\begin{abstract}
Five physicochemical parameters (water content, electrical conductivity, total acidity $(\mathrm{pH})$, ash mass fraction and concentration of free acids) were analyzed in 15 sunflower honeys collected from several localities in Vojvodina, Serbia. The mean values of analyzed honeys were: water content $16.87 \%$; concentration of free acids 27.43 $\mathrm{mEq} / \mathrm{kg}$; electrical conductivity $0.34 \mathrm{mS} / \mathrm{cm} ; \mathrm{pH} 3.64$ and ash mass fraction $0.13 \%$. The selected physicochemical characteristics of all honey samples from Serbia analyzed in this research can be considered to be within the parameters expected for sunflower honey in general. The values for ash mass fraction, electrical conductivity and concentration of free acids in all sunflower honey samples showed similar trends. High correlation was established between electrical conductivity and ash mass fraction. Statistically significant difference $(\mathrm{p} \leq 0.05)$ was established only for average values of free acids concentration between honey samples originating from the localities Kanjiža and Čelarevo. All of the analyzed honey samples were found to meet national and European legislation for investigated parameters
\end{abstract}

Key words: sunflower honey, electrical conductivity, acidity, ash

\section{INTRODUCTION}

Honey is natural food that contains about 200 substances. Besides its main components, glucose and fructose, honey contains water and other substances such as proteins, organic acids, vitamins, minerals, pigments, phenolic compounds, volatile compounds, and solid particles derived from honey harvesting (Bogdanov, Jurendić, Sieber \& Gallmann, 2008; Da Silva, Gauche, Gonzaga, Costa, \& Fett, 2016). The composition, color, aroma and flavor of honey depend mainly of the flower source, climatic conditions, geographical locations, honeybee species, weather conditions, processing, manipulation and storage time (Escuredo, Dobre, Fernández-González \& Seijo,
2014; Karabagias, Badeka, Kontakos, Karabournioti, \& Kontominas, 2014). The physicochemical properties of honey with same floral origin can vary as consequence of different climatic conditions or geographical origin (JuanBorrás, Domenech, Hellebrandova, \& Esriche, 2014).

Honey physicochemical quality criteria are well specified by the European legislation (European Commission, 2002) and the regulation concerning the quality of honey in the Republic of Serbia (Pravilnik, 2015). The major criteria for honey quality and authenticity, in both of those standards are sugar content (sucrose and sum of fructose and glucose), 
moisture content, water-insoluble matter content, electrical conductivity, free acidity, diastase activity and hydroxymethylfurfural (HMF) content. The classical approach to the determination of honey botanical origin includes sensory, melissopalynological and physicochemical analysis (European Commission, 2002). This approach is time-consuming and requires personnel specialized in carrying out sensory and melissopalynological analysis (Lazarević, Andrić, Trifković, Tešić \& Milojković-Opsenica, 2012). Many studies have been carried out to find analytical markers of the botanical and geographical origin of honey. In these studies, physicochemical parameters (Devillers, Morlot, Pham-Delègue \& Doré, 2004; Acquarone, Buera \& Elizalde, 2007; Kirs, Pall, Martverk, \& Laos, 2012; JuanBorrás et al., 2014; Karabagias et al., 2014; El Sohaimy, Masry \& Shehata, 2015; Da Silva et al., 2016), carbohydrate profiles (Kaškonienè, Venskutonis \& Čeksterytè, 2010; Escuredo et al., 2014; Živkov Baloš, Popov, Prodanov Radulović, Stojanov \& Jakšić, 2020), mineral content (Lazarević, 2016; Mračević, Krstić, Lolić \& Ražić, 2020), amino acid composition (Sakač et al., 2019), phenolic content (Sari \& Ayyildiz, 2012; Alqarni, Owayss, \& Mahmoud, 2012; Cimpoiu, Hosu, Miclaus, \& Puscas, 2013), volatile compounds (Juan-Borrás et al., 2014) have been suggested as criteria for the characterization of honeys.

The electrical conductivity (EC), total acidity $(\mathrm{pH})$, and ash mass fraction are related to the concentration of mineral salts, organic acids and proteins (Acquraone et al., 2007; Lazarević, Jovetić, \& Tešić, 2017). The EC is very often used in routine quality control of honey. This parameter is defined as that of a $20 \%$ weight in volume solution in water at $20^{\circ} \mathrm{C}$, where the $20 \%$ refers to honey dry matter (International Honey Commission Methods, 2009). It is used to distinguish between floral and honeydew honeys according to the standard. In accordance with the regulation concerning the quality of honey in the Republic of Serbia (Pravilnik, 2015), the minimum EC in honeydew placed on the market is set at 0.8 $\mathrm{mS} / \mathrm{cm}$. For other types of honey, the maximum permitted value of EC is $0.8 \mathrm{mS} / \mathrm{cm}$. This parameter is also important for the authentication of unifloral honeys (Kaškonienè et al., 2010). Other factors such as floral source, amount of organic acids and proteins, and storage time can also influence the electric conductivity of honey (Karabagias et al., 2014). High electric conductivity values do not necessarily correspond to higher amounts of ash in the honey (Escuerdo et al., 2014). The EC value depends on the ash and acid content in honey: the higher their content, the higher the resulting EC (International Honey Commission Methods, 2009). The ashes of honey give an indication of environmental pollution and hence also an indication of geographical origin. The reference value for the ash mass fraction is not prescribed by the regulations.

The acidity of honey causes the presence of organic acids (tartaric, citric, oxalic, acetic, etc.), nectar or secretions of bees (Yadata, 2014). The acidity of honey can be determined by titration with sodium hydroxide (free acidity) or directly measuring the $\mathrm{pH}$ value $(\mathrm{pH}$ value). The natural acidity of honey can be increased by the storage and ripening of honey, as well as during the fermentation of honey. Honey that is adulterated with sugar syrup has very low acidity $(<1)$, while honey that is adulterated with invert sugar has a pronounced high acidity (Yadata, 2014). The acidity value related to the balance of organic acids naturally present in honey varies according to the floral source and the bee species (Sousa et al., 2016). The maximum value of free acidity in all types of honey (except in baker's honey) is 50 $\mathrm{mEq} / \mathrm{kg}$ (Pravilnik, 2015). The reference value for the total acidity is not prescribed by the national regulations.

Sunflower honey is bright yellow, fragrantsmelling, dry, with an aroma of pollen, slightly herbaceous. This is a traditional honey with exceptional healing properties and nutritional value. It is discovered that sunflower pollen consistently reduced a protozoan pathogen (Crithidia bombi) infection in bumble bees and also reduced a protozoan pathogen (Nosema ceranae) of the honey bee (Apis mellifera) indicating the potential for broad antiparasitic effects (Giacomini et al., 2018). Sunflower honey contains small percentage of sucrose and therefore gets quickly crystallized (Srinual \& Pilairuk, 2009; Sari, \& Ayyildiz, 2012). Sunflower is cultivated only in the southern regions, where there is a lot of sun and where the climate is favorable for growing this plant. In Serbia, honey production is well developed thanks to a suitable climate and geographic location. The beekeeping, which has been sig- 
nificantly developed and maintained in Serbia since the $10^{\text {th }}$ century, is an important agricultural activity (Lazarević, 2016).

The purpose of this study was to determine water content, electrical conductivity, ash and acidity of sunflower honey samples collected from beekeepers in different regions of Vojvodina (northern Serbia), in order to obtain information about the honey quality and safety. In our research, which is part of a study of the physicochemical and sensory characteristics of Serbian unifloral and mixed honey, the behavior of honey was specifically examined with respect to the electrical conductivity and free acidity.

\section{MATERIALS AND METHODS}

\section{Honey samples}

A total of 15 samples of sunflower honey harvested in 2019 were collected from beekeepers in different regions of the Autonomous Province of Vojvodina, Serbia. The sampling included locations in municipalities Kikinda (3 samples), Čelarevo (7 samples) and Kanjiža (5 samples). All collected samples were in their original packaging (jars) and transferred to the laboratory of Scientific Veterinary Institute "Novi Sad" for examination. Manufacturers used field observations for botanical origin determination. Our research included only the samples with confirmed botanical origin stated on the manufacturing specification label. All selected samples were produced by Apis mellifera. Honey analyses were carried out immediately after sampling. The honey analysis procedures were performed in two replicates.

\section{Physicochemical analysis}

\section{Water content}

Water content was determined by refractometry, measuring the refractive index (RI) according to the harmonized methods of the International Honey Commission (International Honey Commission Methods, 2009) using a standard model Abbe type refractometer at $20^{\circ} \mathrm{C}$. Water content (\%) was then obtained from the Chataway table (International Honey Commission Methods, 2009).

\section{Electrical conductivity}

Electrical conductivity was measured at $20^{\circ} \mathrm{C}$ in solutions of honey samples (20.0 g dry matter of honey in volume solution in $100 \mathrm{ml}$ dis- tilled water) using a conductometer Crison (Type Basic 30). The method of measuring is prescribed by International Honey Commission Methods (2009).

\section{Free acidity and $\mathrm{pH}$}

The acidity of honey was determined by volumetric method (International Honey Commission Methods, 2009). Ten grams of honey were dissolved in $75 \mathrm{ml}$ of distilled water, the $\mathrm{pH}$ is measured and solution was titrated with $0.1 \mathrm{M} \mathrm{NaOH}$ to $\mathrm{pH} 8.30$. Acidity is expressed in milliequivalents $/ \mathrm{kg}$ honey $(\mathrm{mEq} / \mathrm{kg})$.

\section{Ash mass fraction}

The ash content of honey means the residue which is obtained by a defined procedure and expressed as a percentage by weight (International Honey Commission Methods, 2009). The honey is ashed at $600{ }^{\circ} \mathrm{C}$ and the residue is weighed.

\section{Statistical analysis}

Statistically significant differences between the individual parameters at different locations were determined using one-way ANOVA (PAST, Version 2.12, Oslo, Norway). Statistical linear regression analysis was performed by the PAST software package, version 2.12, Oslo, Norway. Data were presented as mean, standard deviation, minimum and maximum value.

\section{RESULTS AND DISCUSSION}

Average values of water content, electrical conductivity, acidity, $\mathrm{pH}$ and ash mass fraction of honey obtained in this study are shown in Table 1. The obtained values were compared with the values that are prescribed by the Regulation on the quality of honey in the Republic of Serbia (Pravilnik, 2015). Also, the results were compared with the results from other authors from both Serbia and other countries. ANOVA one way statistical analysis revealed statistically significant difference between the localities Kanjiža and Čelarevo at $\mathrm{p} \leq 0.05$ only for free acidity of honey.

The water content values in all investigated honey samples ranged between $14.60-18.60 \%$ (average $16.87 \pm 1.23 \%$ ). The water content in all investigated honey samples was below the maximum permitted level (20\%) set by regulations for honeys (European Commission, 2002; Pravilnik, 2015). The honey moisture in 
depends on the production season, floral source, abundance of nectar flow, soil, ventilation of the beehive, colony strength, and meteorological conditions in the area of honey production, primarily air humidity (Kirs, Pall, Martverk, \& Laos, 2011; Escuerdo et al., 2014; Sousa et al., 2016; Lazarević et al., 2017). An important factor that could affect the water content is honey maturation and harvest time. According to most of national good beekeeping practice recommendations, beekeeper should harvest honey when at least $2 / 3$ wax combs in frames are covered with wax lids (Živkov Baloš, Jakšić, Popov, Mihaljev \& Ljubojević Pelić, 2019). Values of electrical conductivity in the investigated honey samples were between 0.22 and $0.54 \mathrm{~ms} / \mathrm{cm}$ (average
$0.34 \pm 0.09 \mathrm{mS} / \mathrm{cm})$, which is also below maximum permissible value $(0.8 \mathrm{mS} / \mathrm{cm})$. The data indicate that the lowest average conductivity was in honey samples from the locality Kanjiža, while the highest average conductivity was measured in samples from locality Čelarevo. Similar values for electrical conductivity in sunflower honey were reported by other authors from Serbia, Greece, France, Argentina, Spain, Romania, and Czech Republic (Thrasyvoulou \& Manikis, 1995; Devillers et al., 2004; Acquarone et al., 2007; Juan-Borrás et al., 2014; Lazarević et al., 2012; Mračević et al., 2020). Ash mass fraction is an indicator of the mineral content of honey. This parameter mainly depends on soil and climate characteristics (Acquraone et al., 2007).

\section{Table 1.}

Results of water content, electrical conductivity, acidity, $\mathrm{pH}$ and ash mass fraction in 15 sunflower honey samples from locations in municipalities Kanjiža, Čelarevo and Kikinda

\begin{tabular}{|c|c|c|c|c|c|}
\hline Sample & $\begin{array}{c}\text { Water } \\
(\%)\end{array}$ & $\begin{array}{l}\text { Electrical conductivity } \\
(\mathrm{mS} / \mathrm{cm})\end{array}$ & $\begin{array}{l}\text { Free acidity } \\
(\mathrm{mEq} / \mathrm{kg})\end{array}$ & $\mathbf{p H}$ & $\begin{array}{c}\text { Ash mass } \\
\text { fraction } \\
(\%)\end{array}$ \\
\hline Ka 1 & 18.60 & 0.32 & 24.40 & 3.57 & 0.08 \\
\hline $\mathrm{Ka} 2$ & 16.40 & 0.28 & 20.40 & 3.69 & 0.05 \\
\hline Ka 3 & 18.40 & 0.30 & 20.80 & 3.52 & 0.05 \\
\hline $\mathrm{Ka} 4$ & 15.20 & 0.28 & 23.80 & 3.55 & 0.12 \\
\hline Ka 5 & 14.60 & 0.30 & 22.40 & 3.99 & 0.14 \\
\hline C 1 & 17.40 & 0.36 & 27.20 & 3.64 & 0.11 \\
\hline $\mathrm{C} 2$ & 16.40 & 0.54 & 30.00 & 3.63 & 0.21 \\
\hline C 3 & 16.40 & 0.42 & 36.40 & 3.61 & 0.13 \\
\hline $\mathrm{C} 4$ & 16.00 & 0.22 & 26.80 & 3.46 & 0.09 \\
\hline C 5 & 15.40 & 0.26 & 24.50 & 3.59 & 0.09 \\
\hline C 6 & 17.80 & 0.44 & 34.40 & 3.84 & 0.25 \\
\hline $\mathrm{C} 7$ & 18.20 & 0.46 & 35.60 & 3.62 & 0.30 \\
\hline Ki 1 & 17.80 & 0.30 & 26.40 & 3.63 & 0.09 \\
\hline Ki 2 & 17.60 & 0.32 & 32.20 & 3.70 & 0.09 \\
\hline Ki 3 & 16.80 & 0.30 & 26.20 & 3.68 & 0.10 \\
\hline Mean & 16.87 & 0.34 & 27.43 & 3.64 & 0.13 \\
\hline $\mathrm{SD}$ & 1.23 & 0.09 & 5.19 & 0.13 & 0.07 \\
\hline Min & 14.60 & 0.22 & 20.40 & 3.46 & 0.05 \\
\hline Max & 18.60 & 0.54 & 36.40 & 3.99 & 0.30 \\
\hline
\end{tabular}

Ka -locations in municipality Kanjiža; C-locations in municipality Čelarevo, Ki-locations in municipality Kikinda

Table 2.

Correlation between examined parameters in sunflower honey from Serbia

\begin{tabular}{cccc}
\hline \multicolumn{2}{c}{ Linear regression between: } & Regression Equation & $\mathbf{R}^{2}$ \\
\hline electrical conductivity & ash mass fraction & $\mathrm{y}=0.945 \mathrm{x}+0.220$ & 0.611 \\
electrical conductivity & free acidity & $\mathrm{y}=41.12 \mathrm{x}+13.45$ & 0.476 \\
free acidity & ash mass fraction & $\mathrm{y}=50.81 \mathrm{x}+20.99$ & 0.497 \\
\hline
\end{tabular}


Generally, the ash content is $\leq 0.6 \%(\mathrm{w} / \mathrm{w})$ (Pita-Calvo \& Vásquez, 2017). Obtained values for ash mass fraction in sunflower honeys varied from 0.05 to $0.30 \%$. Average ash mass fraction value was $0.13 \pm 0.07 \%$. High linear correlation between EC and ash mass fraction was found by many authors (Accorti, Piazza \& Persano-Oddo, 1987; Thrasyvoulou, \& Manikis, 1995; Kropf, Jamnik, Bertoncelj \& Golob, 2008; El Sohaimy, Masry,\& Shehata, 2015; Lewoyehu \& Amare, 2019).

Free acidity in all samples tested was below 50 $\mathrm{mEq} / \mathrm{kg}$, indicating the absence of undesirable fermentation. The acidity value in the investigated sunflower honey samples ranged from $20.40 \mathrm{mEq} / \mathrm{kg}$ to $36.40 \mathrm{mEq} / \mathrm{kg}$ (average 27.43 $\pm 5.19 \mathrm{mEq} / \mathrm{kg}$ ), which is in line with the results reported by Devillers et al. (2004), Lazarević et al. (2012), Prica et al. (2014) and Mračević et al. (2020). Free acidity and pH increases with storage time, as well as during fermentation, because honey sugars and alcohols transform into acids by honey yeasts and bacteria (Cavia, Fernández-Muiño, Alonso-Tore, Huidobro, \& Sancho, 2007; Alqarni et al., 2012). Honey pH depends on the content of organic acids and mineral elements and influences microorganisms development, enzymatic activity and texture, among other properties (Cavia et al., 2007; Pita-Calvo \& Vásquez, 2017). As visible from Table 1, the
$\mathrm{pH}$ values in analyzed honey samples ranged from 3.46 to 3.99 (average $3.64 \pm 0.13$ ). This range is consistent with the results for sunflower honey obtained by other authors (Thrasyvoulou \& Manikis, 1995; Sari \& Ayyildiz, 2012; Lazarević et al., 2012; Cimpoiu et al., 2013; Mračević et al., 2020). The $\mathrm{pH}$ values of honey usually range between 3.5 and 5.5 (Pita-Calvo, \& Vásquez, 2017).

The ash mass fraction, electrical conductivity and free acidity values of all sunflower honey samples showed similar trends (Figure 1). Since investigated properties are a function of the concentration of the ions present in the honey, their correlation was examined (Table $2)$. It was found that there is a correlation between electrical conductivity and ash mass, acidity and ash mass, acidity and electrical conductivity. Between other examined parameters, the correlation coefficients were insignificant. Correlation was established between electrical conductivity and ash mass fraction $\left(\mathrm{R}^{2}=0.611\right)$. Correlation between free acidity and electrical conductivity calculated for sunflower honey samples was $\mathrm{R}^{2}=0.476$. In our earlier study that included 55 honey samples (16 samples of acacia honey, 18 samples of meadow honey, 9 samples of multifloral honey, 6 samples of linden honey, and 6 samples of honeydew honey), significant linear correlation between free acidity and electrical con-

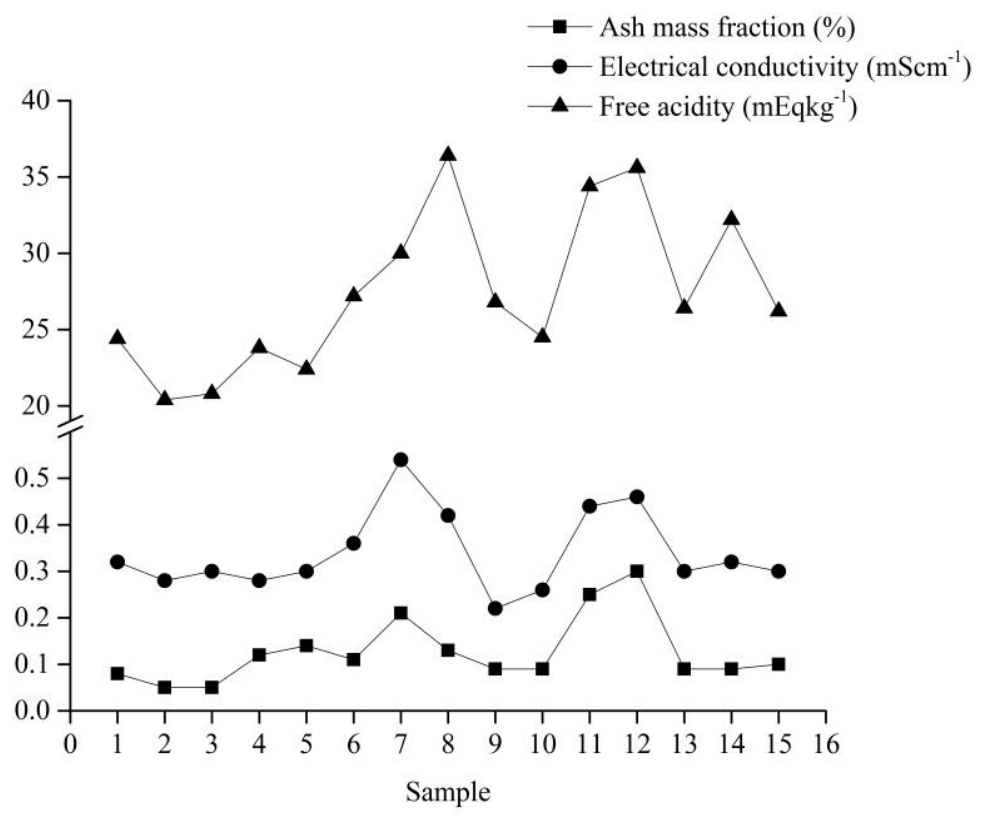

Figure 1. Relations between ash content, electrical conductivity and free acidity values of sunflower honeys 
ductivity was established only for meadow and multifloral honey samples $\left(\mathrm{R}^{2}=0.8210\right.$ and $R^{2}=0.7688$ ). A similar correlation coefficient to that obtained for sunflower honey was found for honeydew honey $\left(\mathrm{R}^{2}=0.4996\right)$ (Živkov Baloš et al., 2018).

\section{CONCLUSIONS}

The water content, electrical conductivity, total acidity, ash mass fraction and concentration of free acids of sunflower honey collected from beekeepers in different regions of the Autonomous Province of Vojvodina, Serbia was determined. Our results demonstrated that Serbian sunflower honey is characterized by good quality since the examined parameters closely related to the quality of honey, showed values in agreement with legal limits established by the national and European legislation. The hypothesis about potential existence of a correlation between the parameters tested was confirmed for electrical conductivity/ash mass, acidity/ash mass fraction, as well as for acidity/electrical conductivity. Likewise, we found that these parameters show similar trends. By observing the geographical characteristics of Serbian sunflower honey, we found statistically significant differences only between average values of free acidity of honey originating from localities of Kanjiža and Čelarevo.

Therefore, further research on physicochemical properties of sunflower honey is required to confirm the quality and authenticity of this product. The importance of such research lies in its contribution to better understanding the benefits of this type of honey.

\section{ACKNOWLEDGEMENTS}

This research was funded by the Ministry of Education, Science and Technological development of Republic of Serbia by the Contract of implementation and financing of scientific research work of NIV-NS in 2020, Contract No: 451-03-68/2020-14/200031 from January 24, 2020.

\section{REFERENCES}

Accorti, M., Piazza, M. G., \& Persano-Oddo, L. (1987). La conductivité électrique et le contenu en cendres du miel. Apiacta, 22, 19-20.

Acquarone, C., Buera, P., \& Elizalde, B. (2007). Pattern of $\mathrm{pH}$ and electric conductivity upon honey dilution as a complementary tool for discriminating geographical origin of honeys. Food Chemistry, 101, 695-703. https://doi.org/10.1016/j.foodchem.2006.01.058

Alqarni, A. S., Owayss, A. A., \& Mahmoud, A. A. (2012). Physicochemical characteristics, total phenols and pigments of national and international honeys in Saudi Arabia. Arabian Journal of Chemistry, 9, 114-120. https://dx.doi.org/10.1016/j.arabjc.2012.11.013

Bogdanov, S., Jurendić, T., Sieber R., \& Gallmann P. (2008). Honey for Nutrition and Health: A review. American Journal of the College of Nutrition, 27, 677-689.

Cavia, M. M., Fernández-Muiño, M. A., Alonso-Tore, S. R., Huidobro, J. F., \& Sancho, M. T. (2007). Evolution of acidity of honeys from continental climates: Influence of induced granulation. Food Chemistry, 100, 1728-1733.

https://doi.org/10.1016/j.foodchem.2005.10.019

Cimpoiu, C., Hosu, A., Miclaus, V., \& Puscas, A. (2013). Determination of the floral origin of some Romanian honeys on the basis of physical and biochemical properties. Spectrochimica Acta Part A: Molecular and Biomolecular Spectroscopy, 100, 149-154.

https://dx.doi.org/10.1016/j.saa.2012.04.008

Da Silva, P. M., Gauche, C., Gonzaga, L. V., Costa, A. C. O., \& Fett, R. (2016). Honey: Chemical composition, stability and authenticity. Food Chemistry, 196, 309-323.

https://dx.doi.org/10.1016/j.foodchem.2015.09.051

Devillers, J., Morlot, M., Pham-Delègue, M. H., \& Doré, J. C. (2004). Classification of monofloral honeys on their quality control data. Food Chemistry, 86, 305-312. https://doi.org/10.1016/j.foodchem.2003.09.029

El Sohaimy, S. A., Masry, S. H. D., \& Shehata, M. G. (2015). Physicochemical characteristics of honey from different origins. Annals of Agricultural Science, 60(2), 279-287. https://dx.doi.org/10.1016/j.aoas.2015.10.015

Escuredo, O., Dobre, I., Fernández-González, M., \& Seijo, M. C. (2014). Contribution of botanical origin and sugar composition of honeys on the crystallization phenomenon. Food Chemistry, 149, 84-90.

https://doi.org/10.1016/j.foodchem.2013.10.097

European Commission (2002). Council Directive 2001/110/EC of 20 December 2001 relating to honey. Official Journal of the European Communities, L10, 47-52.

Giacomini, J. J., Leslie, J., Tarpy, D. R., Palmer-Young, E. C., Irwin, R. E., \& Adler, L. S. (2018). Medicinal value of sunflower pollen against bee pathogenes. Scientific Reports, 8,14394. https://doi.org/10.1038/s41598-018-32681-y

International Honey Commission Methods (IHCM). (2009). Harmonized methods of the International Honey Commission Methods. Liebefeld, Switzerland: Swiss Bee Research Centre, FAM. http://www.bee-hexagon.net/en/network.htm

Juan-Borrás, M., Domenech, E., Hellebrandova, M., \& Esriche, I. (2014). Effect of country origin on physicochemical, sugar and volatile composition of acacia, sunflower and tilia honeys. Food Research International, 60, 86-94. https://dx.doi.org/10.1016/j.foodres.2013.11.045

Karabagias, I. K., Badeka, A. V., Kontakos, S., Karabournioti, S., \& Kontominas, M. G. (2014). Bota- 
nical discrimination of Greek unifloral honeys with physico-chemical and chemometric analyses. Food Chemistry, 165, 181-190.

https://dx.doi.org/10.1016/j.foodchem.2014.05.033

Kaškonienè, V., Venskutonis, P. R., \& Čeksterytė, V. (2010). Carbohydrate composition and electrical conductivity of different origin honeys from Lithuania. Food Science and Technology, 43, 801807. https://doi.org/10.1016/j.lwt.2010.01.007

Kirs, E., Pall, R., Martverk, K., \& Laos, K. (2011). Physicochemical and melissopalynological characterization of Estonian summer honeys. Procedia Food Science, 1, 616-624. https://doi.org/10.1016/j.profoo.2011.09.093

Kropf, U., Jamnik, M., Bertoncelj, J., \& Golob T. (2008). Linear regression model of the ash mass fraction and electrical conductivity for Slovenian honey. Food Technology and Biotechnology, 46(3), 335340.

Lazarević, K. B. (2016). Fizičko-hemijska karakterizacija i klasifikacija meda sa teritorije Republike Srbije prema botaničkom i regionalnom poreklu primenom multivarijantne hemometrijske analize (PhD thesis). Univerzitet u Beogradu, Hemijski fakultet, Beograd, Srbija.

Lazarević, K. B, Andrić, F., Trifković, J., Tešić. Ž. LJ., \& Milojković-Opsenica, D. M. (2012). Characterisation of Serbian unifloral honeys according to their physicochemical parameters. Food Chemistry, 132, 2060-2064.

https://doi.org/10.1016/j.foodchem.2011.12.048

Lazarević, K. B., Jovetić, M. S., \& Tešić, Ž. LJ. (2017). Physicochemical parameters as a tool for the assessment of origin of honey. Journal of AOAC International, 100, 4, 840-851. https://doi.org/10.5740/jaoacint.17-0143

Lewoyehu, M., \& Amare, M. (2019). Comparative assesment on selected physicochemical parameters and antioxidant and antimicrobial activities of honey samples from selected districts of the Amhara and Tigry regions, Ethiopia. Intenational Journal of Food Science, 2019, Article ID 4101695, 10 pages. https://doi.org/10.1155/2019/4101695

Mračević, S. Đ., Krstić, M., Lolić, A., \& Ražić, S. (2020). Comparative study of the chemical composition and biological potential of honey from different regions of Serbia. Microchemical Journal, 152, 104420. https://dx.doi.org/10.1016/j.microc.2019.104420

Pravilnik. (2015). Pravilnik o kvalitetu meda i drugih pčelinjih proizvoda. Službeni glasnik $R S$, $101 / 2015$.

Pita-Calvo, C., \& Vásquez, M. (2017). Differences between honeydew and blossom honeys: A review. Trends in Food Science \& Technology, 59, 79-87. https://dx.doi.org/10.1016/j.tifs.2016.11.015
Prica, N., Živkov-Baloš, M., Jakšić, S., Mihaljev, Ž., Kartalović, B., Babić, J., \& Savić, S. (2014). Moisture and acidity as indicators of the quality of honey originating from Vojvodina region. Archives of Veterinary Medicine, 7(2), 99-109. https://doi.org/10.46784/e-avm.v7i2.135

Sakač, M., Jovanov, P., Marić, A., Tomičić, Z., Pezo, L., Dapčević Hadnađev, T., \& Novaković, A. (2019). Free amino acid profiles of honey samples from Vojvodina (Republic of Serbia). Food and Feed Research, 46(2), 179-187. https://doi.org/10.5937/FFR1902179S

Sari, E., \& Ayyildiz, N. (2012). Biological activities and some physicochemical properties of sunflower honeys collected from the Thrace region of Turkey. Pakistan Journal of Biological Sciences, 15(23), 1102-1110.

https://doi.org/10.3923/pjbs.2012.1102.1110

Srinual, K., \& Pilairuk, I. (2009). Effects of crystallization and processing on sensory and physicochemical qualities of Thai sunflower honey. Asian Journal of Food and Agro-Industry, 2(4), 749-754.

https://www.cabdirect.org/cabdirect/abstract/20103 303353\#

Sousa, J. M. B., Soza, L. E., Marques, G., Benassi. M. T., Gullon, B., \& Pintado, M. M. (2016). Sugar profile, physicochemical and sensory aspects of monofloral honeys produced by different stingless bee species in Brazilian semi-arid region. $L W T$ Food Science and Technology, 65, 645-651. https://dx.doi.org/10.1016/j.1wt.2015.08.058

Thrasyvoulou, A., \& Manikis, J. (1995). Some physicochemical and microscopic characteristics of Greek unifloral honeys. Apidologie, 26(6), 441452. https://hal.archives-ouvertes.fr/hal-00891310

Yadata, D. (2014). Detection of the electrical conductivity and acidity of honey from different areas of Tepi. Food Science and Technology, 2(5), 5963. https://doi.org/10/13189/fst.2014.020501

Živkov Baloš, M., Popov, N., Vidaković, S., Ljubojević Pelić, D., Pelić, M., Mihaljev, Ž., \& Jakšić, S. (2018). Electrical conductivity and acidity of honey. Archives of Veterinary Medicine, 11(1), 91101. https://doi.org/10.46784/e-avm.v11i1.20

Živkov Baloš, M., Jakšić, S., Popov, N., Mihaljev, Ž., \& Ljubojević Pelić, D. (2019). Comparative study of water content in honey produced in different years. Archives of Veterinary Medicine, 12(1), 43-53. https://doi.org/10.46784/e-avm.v12i1.42

Živkov Baloš, M., Popov, N., Prodanov Radulović, J., Stojanov, I., \& Jakšić, S. (2020). Sugar profile of different floral origin honeys from Serbia. Journal of Apicultural Research, 59(4), 398-405. https://doi.org/10.1080/00218839.2020.1714193 


\section{KARAKTERIZACIJA SRPSKOG SUNCOKRETNOG MEDA NA OSNOVU NjEGOVIH FIZIČKO- HEMIJSKIH KARAKTERISTIKA}

Milica M. Živkov Baloš, Sandra M. Jakšić, Nenad C. Popov*, Vladimir A. Polaček

Naučni institut za veterinarstvo „Novi Sad”, 21000 Novi Sad, Rumenački put 20, Srbija

Sažetak: U ovom radu analizirano je pet fizičko-hemijskih parametara (sadržaj vode, električna provodljivost, ukupna kiselost, maseni udeo pepela i koncentracija slobodnih kiselina) u 15 uzoraka suncokretovog meda, prikupljenih sa nekoliko lokaliteta Vojvodine. Srednje vrednosti ispitivanih parametara bile su: voda 16,87\%; koncentracija slobodnih kiselina $27,43 \mathrm{mEq} / \mathrm{kg}$; električna provodljivost $0,34 \mathrm{mS} / \mathrm{cm}$; maseni udeo pepela $0,13 \%$ i pH 3,64. Fizičko-hemijske karakteristike svih ispitanih uzoraka meda mogu se smatrati u okvirima vrednosti koji se očekuju za suncokretov med. Maseni udeo pepela, električna provodljivost i koncentracija slobodnih kiselina u svim uzorcima meda suncokreta pokazali su slične trendove. Utvrđena je visoka korelacija između električne provodljivosti i masenog udela pepela. Samo prosečne vrednosti koncentracije slobodnih kiselina meda, su se statistički značajno razlikovale i to između lokaliteta Kanjiža i Čelarevo $(r=0,017)$. Na osnovu dobijenih vrednosti za ispitivane parametre, utvrđeno je da svi uzorci suncokretovog meda ispunjavaju uslove nacionalnog i evropskog zakonodavstva.dehidrirane pečurke mogu se smatrati novim funkcionalnim (polu)proizvodima, uzimajući u obzir njihov poboljšan nutritivni profil.

Ključne reči: suncokretov med, elektična provodljivost, kiselost, pepeo

Received: 01 December 2020/Received in revised form: 19 January 2021/Accepted: 01 February 2021

Available online: February 2021

This is an open-access article under the CC BY license (http://creativecommons.org/licenses/by/3.0). 